\title{
PENERAPAN HYGIENE DAN SANITASI DI HOTEL GRAND DAFAM BELLA TERNATE
}

\author{
Muliyadi, Muhlisa, Mustafa \\ Environmental Health Department of Health Polytechnic of Ternate \\ Poltekkes Ternate, Jl. Cempaka, Tanah Tinggi Bar., Ternate Sel., Kota Ternate, Maluku Utara \\ E-mail: muliyadi.blues90@gmail.com
}

\begin{abstract}
Implementation Of Hygiene And Sanitation At The Grand Dafam Bella Hotel Ternate Background, Grand Dafam Hotel is a 4-star hotel located in the city of Ternate, North Maluku. The existence of this hotel influences on increasing the number of tourists in Ternate because it is a 4-star hotel at an affordable price. Objective: The purpose of this study was to determine the application of Hygiene and Sanitation at the Grand Dafam Bella Ternate Hotel. Methods: This research design uses observational design with descriptive methods. The sample of this study is the total population, namely environmental and building health, room/room health requirements, sanitation facilities, employees, and food and beverage services at the Grand Dafam Hotel, Ternate. Sampling uses a total sampling technique. Instruments such as observation sheets/inspection forms refer to minister of health regulation Number 80 of 1990 regarding hospitality sanitation requirements and the Director-General of PPM and PLP Decree No. 95 of 1991 concerning Assessment of Hotel Health Examinations. Results: The results showed that the five components studied all met the requirements by accumulation, but some things did not meet the requirements such as a non-permanent waste collection facility. Conclusion: The conclusion of this study is the Hotel Grand Dafam Bella Ternate has implemented Sanitation and Hygiene properly.
\end{abstract}

Keywords: Sanitation; Hygiene; Hotel; implementation

\begin{abstract}
Abstrak: Penerapan Hygiene Dan Sanitasi Di Hotel Grand Dafam Bella Ternate, Latar Belakang: GrandDafam Hotel adalah hotel bintang 4 yang terletak di kota Ternate, Maluku Utara. Keberadaan hotel ini berpengaruh pada peningkatan jumlah wisatawan di Ternate karena merupakan hotel bintang 4 dengan harga terjangkau. Tujuan: Tujuan dari penelitian ini adalah untuk mengetahui penerapan Hygiene and Sanitasi di hotel Grand Dafam Bella Ternate. Metode: Desain penelitian ini menggunakan desain observasional dengan metode deskriptif. Sampel penelitian ini adalah total populasi, yaitu kesehatan lingkungan dan bangunan, persyaratan kesehatan kamar / kamar, fasilitas sanitasi, karyawan, dan layanan makanan dan minuman di Hotel Grand Dafam, Ternate. Pengambilan sampel menggunakan teknik total sampling. Instrumen seperti lembar observasi / formulir inspeksi mengacu pada Peraturan Menteri Kesehatan Nomor 80 Tahun 1990 tentang persyaratan sanitasi perhotelan dan Keputusan Direktur Jenderal PPM dan PLP No. 95 Tahun 1991 tentang Penilaian Pemeriksaan Kesehatan Hotel. Hasil: Hasil penelitian menunjukkan bahwa kelima komponen yang dipelajari semuanya memenuhi persyaratan dengan akumulasi, tetapi beberapa hal tidak memenuhi persyaratan seperti fasilitas penampungan sampah sementara yang tidak permanen. Kesimpulan: Kesimpulan dari penelitian ini adalah Hotel Grand Dafam Bella Ternate telah menerapkan Sanitasi dan Hygiene dengan baik
\end{abstract}

Kata kunci: Sanitasi; Kebersihan; Hotel; pelaksanaan

\section{PENDAHULUAN}

Pada dasarnya Sanitasi lingkungan sangat luas cakupannya, hampir di seluruh kehidupan manusia. Dalam penlitian yang dilakukan oleh WHO mengatakan bahwa angka kematian (mortalitas), angka kematian orang sakit (morbiditas) dan terjadinya epidemi penyakit ditemukan di tempat-tempat yang Hygiene dan Sanitasi lingkungannya buruk, seperti banyak sampah menumpuk, lalat, nyamuk, kondisi air 
yang buruk, keadaan sosial ekonomi yang jelek. Oleh karena itu Sanitasi lingkungan sangat penting guna memutus mata rantai timbulnya berbagai macam penyakit dikemudian hari. (1)

Menurut (2) ada beberapa syarat sarana Sanitasi dikatakan memenuhi syarat diantaranya adalah memenuhi syarat kesehatan lingkungan, apabila memenuhi kebutuhan fisiologis, psikologis dan dapat mencegah penularan penyakit antar pengguna, dan masyarakat sekitarnya (2). Dampak penyakit yang di timbulkan akibat Sanitasi yang buruk antara lain diare $30 \%$, helminethes $25 \%$, penyakit kulit $25 \%$, trachoma $30 \%$, hepatitis A $10 \%$ serta secara tidak langsung mempengaruhi terjadinya malnutrisi sebesar 5\%. Sanitasi menjadi salah satu faktor penting yang mempengaruhi kesehatan manusia.

Usaha penyehatan lingkungan pada tempat tempat umum merupakan upaya untuk mengamankan lingkungan melalui perbaikan dan pengawasan kualitas lingkungan. Salah satu yang menjadi bagian dari penyehatan tempat tempat umum adalah Sanitasi perhotelan. Industri perhotelan merupakan merupakan salah Satu sarana pariwisata memiliki peran penting dalam peningkatan pendapatan di bidang pariwisata. Hotel merupakan suatu industri atau usaha jasa dengan pengelolaan secara komersial (3)

Penyehatan lingkungan Hotel dilakukan dengan cara penilaian determinan penyebab gangguan kesehatan disebabkan oleh kegiatan operasional Hotel. Permasalahan yang muncul akibat kegiatan operasional Hotel antara lain permasalahan Sanitasi yang mencankup penyediaan air minum dan air bersih yang sehat, pengolahan limbah perhotelan dan penyehatan makanan perhotelan (4).

Hotel Grand Dafam merupakan Hotel bintang 4 yang berada di Kota Ternate, Maluku Utara, keberadaan Hotel ini memberi pengaruh terhadap peningkatan jumlah wisatawan di Kota Ternate karena merupakan Hotel dengan yang tergolong sangat baik. Oleh karena itu peneliti tertarik untuk mengetahui bagaimana Sanitasi dan Hygiene Hotel Grand Dafam Bella Ternate. Melihat biaya Hotel yang tergolong terjangkau dengan status bintang 4 .

Penelitian ini sangat penting dikarenakan akan sangat berkontribusi terhadap saran pemilihan Hotel bagi wisatawan yang berkunjung ke Ternate.

\section{BAHAN DAN CARA PENELITIAN}

Desain penelitian menggunakan desain observasional dengan metode deskriptif yakni metode penelitian melihat gambaran fenomena yang terjadi pada suatu populasi tertentu (5). Penelitian ini bertujuan memberikan gambaran implementasi Hygiene dan Sanitasi Hotel Grand Dafam Bella Ternate. Populasi dalam penelitian seluruh area yang menjadi persyaratan penilaian Sanitasi perhotelan. Sedangkan Teknik sampel dilakukan dengan purposive sampling yakni dengan melakukan kriteria dalam pemilihan sampel. Kriteria sampel adalah area dan atau kamar Hotel yang diberikan izin oleh penanggung jawab Hotel Grand Dafam Bella Ternate sebagai sampel untuk dilakukan penilaian Hygiene dan Sanitasi.

Penggunaan instrumen dalam penelitian ini seperti lembar observasi/ formulir inspeksi berdasarkan (6) tentang persyaratan Sanitasi perhotelan dan alat tulis menulis. Pengumpulan dilakukan melalui pengambilan data primer dilakukan melalui wawancara dan lembar observasi sesuai (6) tentang persyaratan Sanitasi perhotelan serta pengambilan data sekunder dari pihak penanggung jawab Hotel Grand Dafam Bella Ternate.

Alat yang digunakan adalah environmental multimeter, dimana alat ini mampu mengukur kelembaban, suhu, kebisingan, pencahayaan dan kecepatan angin. Bahan-bahan yang digunakan dalam penelitian ini adalah peralatan tulis menulis seperti pulpen dan buku.

Inspeksi dilakukan pada saat pagi hari yaitu pada jam 9 hingga jam 15 sore, dengan terlebih dahulu meminta izin dari pihak hotel yang kemudian dilanjutkan 
dengan koordinasi terkait waktu pelaksanaan.

Objek penelitian ini adalah Lingkungan Luar Hotel meliputi; lokasi,lingkungan dan bangunan Hotel, Lingkungan Dalam Hotel meliputi; tataruang, konstruksi, kamar tidur, kamar linen,ruang cuci dan Gudang, Fasilitas Sanitasi meliputi: penyediaan air bersih, pembuangan limbah cair, toilet umum, kamar mandi dan jamban untuk tamu, pembuangan sampah dan pencegahan serangga dan tikus, Fasilitas Karyawan Hotel meliputi:pakaian kerja, ruang istirahat, kamar mandi dan jamban untuk karyawan, serta penyehatan makanan minuman

Pengolahan dan analisis data dilakukan secara deskriptif dan diinformasikan melalui sajian tabel dan diskripsinya dengan berpedoman pada (7) tentang persyaratan Sanitasi perhotelan. Hotel Layak (sehat) jika memenuhi syarat minimal yakni $75 \%$ dari keseluruhan variabel yang dilakukan penilaian.

\section{HASIL DAN PEMBAHASAN}

Tabel 1. Persyaratan Kesehatan Lingkungan

\begin{tabular}{lll}
\hline No & Komponen & Keterangan \\
\hline A & Umum & \\
1 & Lokasi & Memenuhi Syarat \\
2 & Lingkungan & Memenuhi Syarat \\
3 & Bangunan & Memenuhi Syarat \\
B & Penggunaan ruangan & \\
1 & Pembagian ruangan & Memenuhi Syarat \\
C & Konstruksi & \\
1 & Lantai & Memenuhi Syarat \\
2 & Dinding & Memenuhi Syarat \\
3 & Atap & Memenuhi Syarat \\
4 & Langit-langit & Memenuhi Syarat \\
5 & Pintu & Memenuhi Syarat \\
6 & Pencahayaan & Memenuhi Syarat \\
\hline
\end{tabular}

Berdasarkan Table 1 dapat di simpulkan bahwa persyaratan kesehatan lingkungan Hotel Grand Dafam Bella Ternate sudah memenhi syarat berdasarkan (6)tentang persyaratan Sanitasi perhotelan (7) tentang Penilaian Pemeriksaan Kesehatan Hotel

Tabel 2. Persyaratan Kesehatan Kamar/Ruangan

\begin{tabular}{lll}
\hline No & \multicolumn{1}{c}{ Komponen } & \multicolumn{1}{c}{ Keterangan } \\
\hline A & Umum & Memenuhi Syarat \\
1 & Kondisi Ruangan & \\
B & Khusus & Memenuhi Syarat \\
1 & Kamar tidur & Memenuhi Syarat \\
2 & Ruang istirahat pegawai & Memenuhi Syarat \\
3 & Kamar mandi, jamban & Memenuhi Syarat \\
4 & Ruang cuci & Memenuhi Syarat \\
5 & Gudang & \\
\hline
\end{tabular}

Berdasarkan Tabel 2 dapat di simpulkan bahwa persyaratan kesehatan Kamar/Ruangan Hotel Grand Dafam Bella
Ternate hampir semua sudah memenhi syarat berdasarkan (6) tentang persyaratan Sanitasi perhotelan dan (7) 
tentang Penilaian Pemeriksaan Kesehatan

tidak memenuhi Syarat.

Hotel akan tetapi hanya kamar Lena yang

Tabel 3. Persyaratan Kesehatan Fasilitas Sanitas

\begin{tabular}{lll}
\hline No & \multicolumn{1}{c}{ Komponen } & \multicolumn{1}{c}{ keterangan } \\
\hline 1 & Kualitas air & Memenuhi Syarat \\
2 & Kuantitas air & Memenuhi Syarat \\
3 & Pembuangan limbah cair & Memenuhi Syarat \\
4 & Toilet umum & Memenuhi Syarat \\
5 & Kamar mandi yang digunakan tamu & Memenuhi Syarat \\
6 & Tempat sampah & Memenuhi Syarat \\
7 & Tempat penyimpanan sampah sementara & Tidak Memenuhi Syarat \\
8 & Peralatan pencegahan tikus & Memenuhi Syarat \\
\hline
\end{tabular}

Berdasarkan Table 3 dapat di simpulkan bahwa persyaratan kesehatan fasilitas Sanitasi Hotel Grand Dafam Bella Ternate hampir semua sudah memenhi syarat berdasarkan (6) tentang persyaratan Sanitasi perhotelan dan (7) tentang Penilaian Pemeriksaan Kesehatan Hotel akan tetapi hanya Komponen tempat pengumpulan sampah sementara yang tidak, dengan kondisi tidak permanen.

Tabel 4. Karyawan

\begin{tabular}{lll}
\hline No & \multicolumn{1}{c}{ Komponen } & \multicolumn{1}{c}{ Keterangan } \\
\hline 1 & Seragam kerja & Memenuhi Syarat \\
2 & Keterangan sehat dari dokter yang masih berlaku & Memenuhi Syarat \\
3 & Sertifikat bagi pengolah makanan & Memenuhi Syarat \\
4 & Test rectalswab pada penjamah makanan & Memenuhi Syarat \\
\hline
\end{tabular}

Berdasarkan Table 4 dapat di simpulkan bahwa persyaratan kesehatan Karyawan Hotel Grand Dafam Bella Ternate semua komponen sudah memenhi syarat berdasarkan (6) tentang persyaratan Sanitasi perhotelan dan (7) tentang Penilaian Pemeriksaan Kesehatan Hotel.

Tabel 5. Pelayanan Makanan dan Minuman

\begin{tabular}{lll}
\hline No & \multicolumn{1}{c}{ Komponen } & \multicolumn{1}{c}{ Keterangan } \\
\hline 1 & Dapur & Memenuhi Syarat \\
2 & Ruang makan & Memenuhi Syarat \\
3 & Bahan makanan dan makanan siap saji & Memenuhi Syarat \\
4 & Peralatan dan persediaan & Memenuhi Syarat \\
\hline
\end{tabular}

Berdasarkan Table 5 dapat di simpulkan bahwa persyaratan Pelayanan Makanan dan Minuman Hotel Grand Dafam Bella Ternate semua sudah memenhi syarat berdasarkan (6) tentang persyaratan Sanitasi perhotelan (7)tentang Penilaian Pemeriksaan Kesehatan Hotel.
Berdasarkan perhitungan skor diketahui bahwa untuk persyaratan Hygiene dan Sanitasi pada Hotel Grand Dafam Bella Ternate mendapatkan skor 1054 dari total skor penilaian sebesar 1153. Sehingga persentasi sebesar 91\%. Hal ini menunjukan bahwa Hotel Grand Dafam Bella Ternate telah memenuhi persyaran sesuai dengan (7). 


\section{Persyaratan Kesehatan Lingkungan}

Berdasarkan hasil pengamatan dilapangan didapatkan bahwa keseluruhan komponen pada variable persyaratan kesehatan lingkungan dan bangunan sudah memenuhi syarat dengan rincian lokasi terhindar dari pencemar biologi, fisik, kima dan tidak terletak di daerah potensi banjir. Lingkungan Hotel Grand Dafam tergolong dalam kategor bersih, tidak memungkinkan tikus untuk berkembang biak dan berpagar kuat, sementara bangunan termasuk kategori kokoh.

Lingkungan yang tercemar logam berat di tanah seperti $\mathrm{Pb}, \mathrm{Cu}$,dan $\mathrm{Zn}$ menimbulkan bahaya kesehatan yang serius bagi penduduk(8).

Air (komponen lingkungan) dikatakan memiliki potensi menimbulkan penyakit kalau di dalamnya terdapat bakteri Salmonella typhi, bakteri Vibrio cholera, atau air tersebut mengandung bahan kimia beracun seperti pestisida, logam berat, dan lainnya. Demikian pula, udara dikatakan berbahaya kalau mengandung racun, atau jamur. Udara dikatakan sehat atau air dikatakan bersih kalau di dalamnya tidak mengandung satu atau lebih agent penyakit. Selain itu, agent juga dapat berpindah-pindah dari satu media ke media lainnya(8).

Bangunan Hotel tergolong aman dari potensi Bencana, hal ini menjadi point penting dalam meningkatkan status Hotel Grand Dafam Bella. Banjir memunculkan dampak langsung terhadap keselamatan dan kesehatan jiwa seperti kematian karena tenggelam dan terseret arus banjir, luka dan tersengat listrik. Dampak lanjutan banjir ialah muncul dan meningkatnya penyakit menular, bahkan sampai menimbulkan wabah. Penyakit menular menyebar melalui air (water borne disease) dan timbul akibat lingkungan yang tidak bersih (vector borne disease). Menurut Kementerian Kesehatan RI, ada 7 penyakit yang sering muncul akibat banjir, yaitu diare, leptospirosis, ISPA, penyakit kulit, penyakit saluran pencernaan, tifoid, dan demam berdarah atau malaria(9)
Berdasarkan hasil pengamatan dilapangan kondisi bangunan Hotel Grand Dafam Bella Ternate sangat kokoh dan tidak memiliki potensi untuk runtuh. Keselamatan dan keamanan bangunan tidak lepas dari masalah topografi dan kondisi tanah sehingga perencanaan bangunan atau lingkungan harus dapat menyesuaikan kondisi geologi, geografi dengan arif dan bijak (10)

Berdasarkan hasil pengamatan Hotel Grand daffam Bella Ternate tergolong bebas terhadap tikus dan vector lainnya. Hal ini tentunya akan berdampak positif bagi Hotel dan pengunjung. Adapun bahaya dari vector terutama tikus dapat menyebabkan beberapa penyakit seperti leptospirosis seperti yang dinyatakan dalam penelitian (11) yang menyatakan bahwa ada hubungan antara keberadaan tikus dengan kejadian leptospirosis. Berdasarkan penelitian yang dilakukan oleh (12) menunjukkan ada hubungan bermakna antara keberadaan tikus di dalam dan sekitar rumah dengan kejadian leptospirosis berat $(p<0,0001)$ dan adanya tikus di dalam dan sekitar rumah mempunyai risiko 38,1 kali lebih besar untuk terjadinya leptospirosis berat dibandingkan tidak ada tikus di dalam dan sekitar rumah. Faktor lingkungan yang mempengaruhi kejadian leptospirosis berat yaitu kondisi selokan buruk dan adanya tikus/wirok di dalam dan atau sekitar rumah (13)

Berdasarkan hasil pengamatan Penggunaan ruangan pada Hotel Grand Dafam Bella Ternate sudah sesuai peruntukkan dimana hal ini sudah memenuhi persyaratan yang di syaratkan oleh sesuai dengan (7).

Konstruksi bangunan Hotel sudah memenuhi syarat secara keseluruhan mulai dari lantai yang bersih, berbahan kuat, kedap air, dan juga dengan permukaan rata serta tidak licin dan tidak menimbulkan genangan. Atap bangunan juga tidak bocor dan tidak memungkinkan terjadinya genangan air . Adapun dinding dari bangunan Hotel sangat bersih dengan permukaan yang kedap air dan mudah dibersihkan serta berwarna terang 
sehingga serangga dan vector pengganggu tidak suka. Seperti yang dikatakan oleh (14) yang mengatakan bahwa Mengenakan celana panjang dan baju lengan panjang yang berwarna terang saat bepergian antara senja dan malam hari karena pada saat itu umumnya nyamuk menggigit dan nyamuk sangat suka dengan pakaian yang berwarna gelap. Akan tetapi untuk pencahayaan hanya pencahayaan di ruang relax saja yang terukur yaitu > 30 Lux untuk di daerah lain tidak memenuhi persyaratan. Pencahayaan yang kurang sangat berisiko terhadap seluruh komponen yang ada di Hotel. Kualitas dari pencahayaan memiliki dampak terhadap kemampuan pekerja dalam melihat sesuatu dengan jelas pada saat melakukan pekerjaan di area kerja(15)

\section{Persyaratan kesehatan kamar dan ruangan}

Kondisi ruangan dan kamar tidur di Hotel Grand Dafam Bella Ternate sudah memenuhi syarat dengan rincian tidak pengap dan bersih dengan suhu $18-28^{\circ} \mathrm{C}$, kelembaban 40-70\%. Adapun ruang istirahat dan kamar mandi, jamban dan peturasan sudah memenuhi syarat dimana jamban dikategorikan bersih dengan aliran air lancar serta SPAL yang tertutup. Untuk ruang cuci dan gudang juga dapat dikategorikan bersih, barang yang disimpan digudang di susun dengan rapi dengan menggunakan rak minimal 20 $\mathrm{cm}$. Bahaya dari air yang tidak bersih adalah terjadinya penyakit diare. Salah satu faktor yang paling sering diteliti adalah faktor lingkungan yang meliputi sarana air bersih, Sanitasi, jamban, saluran pembuangan air limbah, kualitas bakteriologis air dan kondisi rumah. (16). SPAL yang terbuka juga memungkinkan adanya genangan dan terjadinya penyumbatan sehingga menjadi sarang vektor penyakit seperti lalat, tikus, kecoa dan lainnya. Daerah perkotaan dapat mengalami ancaman bahaya kesehatan yang serupa bilamana sejumlah besar air limbah dibuang ke saluran terbuka dengan kemungkinan terjadi penyumbatan(17).Berdasaarkan penelitian yang dilakukan oleh (18) menyatakan bahwa Ada hubungan yang signifikan antara kondisi saluran pembuangan air limbah dengan kejadian diare pada balita di Wilayah Kerja Puskesmas Adiwerna Kabupaten Tegal dengan nilai $\mathrm{p}=0,03$. bahaya spal yang tidak memenuhi syarat juga dinyatakan dalam penelitian (19) yang mengatakan bahwa ada hubungan antara sarana pembuangan limbah dengan kejadian Leptospirosis. Nilai odds ratio (OR) = 4,600 dengan interval 1,631-12,973, yang berarti bahwa responden dengan sarana pembuangan limbah tidak memenuhi syarat memiliki risiko 4,6 kali lebih besar menderita leptospirosis bila dibandingkan responden dengan sarana pembuangan limbah memenuhi syarat.

Suhu yang terlalu tinggi pada ruangan akan sangat berpengaruh terhadap kesehatan seperti yang dinyatakan oleh (20) Nilai kenyamanan suhu hanya dibatasi pada kondisi udara tidak ekstrim (moderate thermal Environment), dimana manusia tidak memerlukan usaha apapun,seperti halnya menggigil atau mengeluarkan keringat.Dalam rangkamempertahankan suhu tubuh agar tetap normal sekitar 370C. Kelembaban yang buruk akan berdampak pada penurunan suhu tubuh seperti yang dinyatakan oleh (21) Kecepatan pengeluaran panas tubuh tergantung dari faktor lingkungan, diantaranya adalah suhu dan kelembaban relatif udara. Semakin meningkat kelembaban udara, semakin meningkat pula suhu tubuh saat latihan dan sebaliknya semakin menurun kelembaban relatif udara maka suhu tubuh akan semakin menurun. Perubahan suhu tubuh ini tidak terus menurun, akan tetapi diatur oleh sistem saraf. Peningkatan panas tubuh berkelanjutan dapat disebabkan karena latihan fisik berkelanpanjangan dalam waktu yang lama yang dilakukan dalam ruangan dengan kelembaban yang tinggi. Peningkatan sehu tubuh ini dapat disebabkan karena menurunnya cairan tubuh akibat dari pengeluaran keringat berlebih. Untuk menanggulangi 
penurunan cairan tubuh maka perlu mengkonsumsi cairan yang sesuai dengan cairan yang keluar.

\section{Fasilitas Sanitasi}

Kualitas air yang terpantau sudah memenuhi syarat, begitu juga dengan kuantitas yang sudah memenuhi syarat untuk Hotel berbintang 4 dengan persediaan $750 \mathrm{~L} / \mathrm{hari} / \mathrm{tt}$ dengan penyediaan disetiap tempat dengan menggunakan system perpipaan dan terhindar dari cemaran silang. Menurut (22), perencanaan sebuah gedung yang mempunyai jumlah penghuni lebih dari 500 orang atau jumlah pengunjung lebih dari 1.500 orang harus mempunyai perancangan sistem plambing.

kamar mandi di Hotel Grand Dafam Bella Ternate juga sudah tergolong baik dimana rincian bersih dan tidak berbau, letaknya tidak berhubungan langsung dengan dapur, kamar tidur, dan ruang tamu, dimana lantai kedap air dan terpisah antara toilet laki-laki dan perempuan.

Akan tetapi tempat pengumpulan sampah sementara masih tidak permanen sehingga akan sangat berisiko terhadap infeksi silang vector. Hal ini juga berpotensi berbahaya bagi kesehatan pengguna seperti yang dikatakan oleh (Iswanto dkk, 2016) menyatakan bahwa Sampah B3 rumah tangga berisiko terhadap keselamatan dan kesehatan bagi keluarga, masyarakat, petugas/pekerja, pemulung dan pengepul sampah. Hal yang sama juga dinyatakan oleh (24) dengan mengatakan bahwa Permasalahan sampah di suatu kawasan meliputi tingginya laju timbulan sampah, kepedulian masyarakat yang masih rendah sehingga suka berperilaku membuang sampah sembarangan, keengganan untuk membuang sampah pada tempat yang sudah disediakan. Perilaku yang buruk ini seringkali menyebabkan bencana di musim hujan karena darainase tersumbat sampah sehingga terjadi banjir (24).

Akibat dari penumpukan sampah akan menjadi sarang bagi vektor dan rodent. Salah satu masalah kesehatan yang terjadi adalah penyakit diare dan penyakit kulit pada musim hujan. Penyakit tersebut berawal dari genangan air di tumpukan sampah kemudian menjadi sarang bagi vektor dan rodent sehingga menyebabkan seseorang terkena penyakit(Zamzami et al, 2016).

Ada Beberapa factor penting yang sangat mempengaruhi pengolahan sampah dan dianggap sebagai penghambat seperti penyebaran dan kepadatan penduduk, sosial ekonomi dan karakteristik lingkungan fisik, sikap, perilaku serta budaya yang ada di masyarakat. Penyakit bawaan vector merupakan salah satu penyakit akbiat sampah yang banyak dijumpai di Indonesia sebagai akibat banyaknya vekor yang menjadikan sampah media perkembangbiakannya. (26)

\section{Karyawan}

Seluruh karyawan di Hotel Grand dafa Bella Ternate sudah dilengkapi dengan pakaian kerja yang lengkap dengan kondisi yang bersih dan utuh/tidak sobek. Seluruh karyawan juga telah memiliki surat keterangan sehat dari dokter. Seluruh karyawan juga telah memiliki sertifikat khusus penyehatan makanan bagi petugas pengolah makanan. Pemeriksaan rectal swab juga telah dilakukan kepada seluruh penjamah makanan.

\section{Pelayanan makanan dan minuman}

Kondisi dapur juga sudah tergolong sangat baik dimana tersedia pencucian peralatan, penyimpanan bahan makanan, pengolahan, persiapan, serta tempat administrasi, dengan luas dapur lebih dari $40 \%$ dari ruang makan. Dapur juga sudah memiliki alat untuk pengeluaran udara panas dan bau-bauan. Adapun ruang makan sudah tergolong bersih dengan ukuran ruangan $2,8 \%$ dari meja makan dan tersedia tempat cuci tangan. Kondisi bahan makanan jadi juga sangat baik dan disajikan dengan penyajian memenuhi syarat. Perlengkapan juga sangat bersih, tidak berkarat, dan tahan karat dan tidak memungkinkan untuk kuman untuk berkembang biak. Dari fasilitas Sanitasi 
yang tidak memenuhi syarat dapat menyebabkan terjadinya tempat perkembangbiakan vektor penyakit yang dapat menularkan penyakit melalui makanan. Menurut raras untuk meningkatkan kualitas makanan perlu adanya pengelolaan makanan yang baik sesuai dengan persyatan hiegine dan Sanitasi makanan. Di Amerika Serikat 25 $\%$ dari semua penyebaran penyakit melalui makanan, disebabkan pengolah makanan yang terinfeksi dan higiene perorangan yang buruk ( Maria Yn, 2011). resiko terjadinya penyakit yang disebabkan oleh makanan yang tercemar bakeri seperti yang dinyatakan oleh (Awuy SC et al, 2018) yang mengatakan bahhwa Efek kesehatan terhadap adanya E.coli pada air bersih maupun makanan jadi dapat menybabkan adanya penyakit diare pada semua kelompok umur (29). E.coli juga dapat menyebabkan kolera, bakteri ini mengeluarkan toksin LT (termolabi) atau ST (termostabil). Toksin

\section{KESIMPULAN DAN SARAN}

Kesimpulan dari penelitian ini adalah Sanitasi dan Hygiene di Hotel Grand Dafam Bella Ternate sudah diterapkan dengan baik. Sebaiknya pihak hotel menyediakan tempat penampungan sampah yang permanen.

\section{KEPUSTAKAAN}

1. Who. State Of Global Air /2018 A Special Report On Global Exposure To Air Pollution And Its Disease Burden I. Special Re. Ma:Health Effects Institute. Boston: Ma:Health Effects Institute.; 2018.

2. Kementerian Kesehatan. Peraturan Menteri Kesehatan Republik Indonesia Nomor 44 Tahun 2014 Tentang Penyelenggaraan Pelabuhan Dan Bandar Udara Sehat. 2014. 1-11 Hal.

3. Pertiwi Vw, Andriani R. Penerapan Hygiene Dan Sanitasi Di Pastry Hotel Hilton Bandung. J Pariwisata [Internet]. 2016;Ii(1):62-76.

4. Depkes Ri. Profil Kesehatan Indonesia 2001 Menuju Indonesia Sehat 2010. Vol. 2002:40. Jakarta; dikeluarkan saat bakteri melekat pada sel epitel mukosa usus. E.coli juga dapat menyebabkan infeksi saluran urin dan juga penyakit lain seperti pneumonia, meningitis dan traveler's diarrhea. Selain itu, bakteri ini merupakan agent penyebab penyakit diare. Infeksi E.coli dapat diobati dengan antibiotika namun hasil penelitian dari (28) menunjukkan adanya kemampuan resistensi dari bakteri ini terhadap beberapa jenis antibiotik. Bakteri ini bisa menyebabkan kematian karena toksin yang dihasilkan lebih banyak pada saat bakteri mati. Penelitian yang dilakukan oleh (30) mengatakan bahwa pada Lokasi sebagian besar sebanyak 17 pedagang tidak memenuhi syarat karena tempat menjajakan dekat dengan jalan raya terletak dekat dengan sumber pencemar seperti makanan mencari lokasi minimal $100 \mathrm{~m}$ dari sumber pencemar, kondisi makanannya dalam kondisi tertutup.

\section{1.}

5. Notoatmodjo S. Promosi Kesehatan Teori Dan Aplikasi. Jakarta: Pt Rineka Cipta; 2010.

6. Permenkes. Permenkes No. 80/Menkes/Per/Ii/1990 Tentang Persyaratan Kesehatan Hotel. 1990.

7. Ditjen Ppm, Plp. Keputusan Ditjen Ppm Dan Plp No 95 Tahun 1991 Tentang Persyaratan Sanitasi Perhotelan [Internet]. 1991.

8. Trisna Y. Kualitas Air Dan Keluhan Kesehatan Masyarakat Di Sekitar Pabrik Gula Watoetoelis. J Kesehat Lingkung. 2018;10(2):220-30.

9. Harthana T, Soedirham O. Faktor Determinan Perilaku Cuci Tangan Pakai Sabun Saat Banjir Bengawan Solo Di Bojonegoro. J Promkes. 2014;2(2):160-72.

10. Hardiman G. Kenyamanan Dan Keamanan Bangunan Ditinjau Dari Kondisi Tapak, Bahan Dan Utilitas. J Desain Dan Konstr. 2006;5(1):47-57.

11. Auliya R. Unnes Journal Of Public Health. Unnes J Public Heal. 2014;3(1):1-10. 
12. Rejeki Dss. Terhadap Kejadian Leptospirosis Berat ( Studi Kasus Di Rumah Sakit Dr . Kariadi Semarang ) Program Pascasarjana. Universitas Diponegoro Semarang; 2005.

13. Suratman. Analisis Faktor Risiko Lingkungan Dan Perilaku Yang Berpengaruh Terhadap Kejadian Leptospirosis Berat Di Kota Semarang. Universitas Diponegoro Semarang; 2006.

14. Purnama Sg. Buku Ajar Pengendalian Vektor [Internet]. Ilmu Kesehatan Masyarakat. 2015. 115 Hal. Tersedia Pada: Www.Simdos.Unud.Ac.Id

15. Rahmayanti D, Artha A. Analisis Bahaya Fisik: Hubungan Tingkat Pencahayaan Dan Keluhan Mata Pekerja Pada Area Perkantoran Health, Safety, And Environmental (Hse) Pt. Pertamina Ru Vi Balongan. J Optimasi Sist Ind. 2015;14(1):71-98.

16. Adisasmito W. Faktor Risiko Diare Pada Bayi Dan Balita Di Indonesia: Systematic Review Penelitian Akademik Bidang Kesehatan Masyarakat. Human-Centric Comput Inf Sci. 2017;7(1):1-10.

17. Ikhwan Z. Faktor Individu Dan Keadaan Saluran Pembuangan Air Limbah ( Spal ) Rumah Tangga Dengan Kejadian Diare Di Rt 01 Rw 09 Kelurahan Sei Jang Kecamatan Bukit Bestari Kota Tanjungpinang. J Kesehat. 2012;4(2):416-9.

18. Sidhi An, Raharjo M, Dewanti Nay. Bakteriologis Air Bersih Terhadap Kejadian. J Kesehat Masy. 2016;4(Juli):665-76.

19. Auliya R. Unnes Journal Of Public Health. Unnes J Public Heal. 2014;3(3):1-10.

20. Kotta Mh. Suhu Netral Dan Rentang Suhu Nyaman Manusia Indonesia (Studi Kasus Penelitian Pada Bangunan Kantor Di Makassar). Metropilar - J Ilm Fak Tek. 2008;6(1):23-9.

21. Sandi I, Ariyasa I, Teresna I, Ashadi K. Pengaruh Kelembaban Relatif Terhadap Perubahan Suhu Tubuh Latihan. Sport Fit J. 2017;5(1):103-9.
22. Standar Nasional Indonesia. Tata Cara Perencanaan Sistem Plambing. Standar Nasional Indonesia (Sni)-037065-2005. 2005.

23. Iswanto, Sudarmadji, Tri Wahyuni E, Sutomo Ah. Timbulan Sampah B3 Rumahtangga Dan Potensi Dampak Kesehatan Lingkungan Di Kabupaten Sleman , Yogyakarta ( Generation Of Household Hazardous Solid Waste And Potential Impacts On Environmental Health In Sleman Regency , Yogyakarta J Jurusan Kesehatan Lingku. J Mns Dan Lingkung. 2016;23(2):179-88.

24. Hardiatmi S. Pendukung Keberhasilan Pengelolaan Sampah Kota. J Inov Pertan. 2011;10(Mei):50-66.

25. Elamin $\mathrm{Mz}$, Nuril Ilmi $\mathrm{K}$, Tahrirah $\mathrm{T}$, Ahmad Zarnuzi Y, Citra Suci Y, Ragil Rahmawati D, Et Al. Analysis of Waste Management In The Village of Disanah , District Of Sreseh. J Kesehat Lingkung. 2016;10(Oktober):368-75.

26. Masyhuda, Hestiningsih R, Rahadian R. Survei Kepadatan Lalat Di Tempat Pembuangan Akhir (Tpa) Sampah Jatibarang Tahun 2017. J Kesehat Masy. 2017;5(Oktober):560-9.

27. Adam Ymnn. Pengetahuan Dan Perilaku Higiene Tenaga Pengolah Makanan Di Instalasi Gizi Rumah Sakit Umum Daerah Dr. Kanujoso Djatiwibowo Balikpapan. 2011.

28. Awuy Sc, Sumampouw Oj, Boky Hb. Kandungan Escherichia Coli Pada Air Sumur Gali Dan Jarak Sumur Dengan Septic Tank Di Kelurahan Rap-Rap Kabupaten Minahasa Utara Tahun 2018 Pendahuluan Air Merupakan Salah Satu Sarana Utama Untuk Meningkatkan Derajat Kesehatan Masyarakat , Untuk Menjamin T. J Kesmas. 2018;7:1-6.

29. Sumampouw 0j, Soemarno, Andarini S, Sriwahyuni E. Environment Risk Factors Of Diarrhea Incidence In The Manado City. Public Heal Res. 2015;5(5):139-43. 
30. Ningsih R. Penyuluhan Hygiene Sanitasi Makanan Dan Minuman, Serta Kualitas Makanan Yang
Dijajakan Pedagang Di Lingkungan Sdn Kota Samarinda. J Kesehat Masy. 2014;10(1):64-72. 